\title{
Role of asbestos and other fibres in the development of diffuse malignant mesothelioma
}

Descriptions of diffuse malignant mesothelioma date from the nineteenth century ${ }^{1}$ but it was not until 1960 that Wagner et $a l^{2}$ described a series of cases of pleural mesothelioma from South Africa and linked them to crocidolite asbestos exposure. Malignant mesotheliomas may arise from the pleura, peritoneum, and pericardium and all may be associated with asbestos exposure. Malignant mesothelioma of the pleura should be distinguished from the so called localised pleural mesothelioma (pleural fibroma), which is rarely malignant ${ }^{3}$ and which is not associated with asbestos exposure. Malignant mesothelioma is an uncommon tumour with an annual male incidence of 7-13/1 000000 and a female incidence of 1-2/ 1000000 in the United States. ${ }^{4}$ In Great Britain the death rate (equivalent to the incidence) in 1983 was $17.5 /$ 1000000 for men and $3 \cdot 2 / 1000000$ for women. ${ }^{5}$ The average age at presentation is about 60 years but occasionally cases have occurred in children and young adults. ${ }^{67}$ There is a long latent interval between first exposure to asbestos and the development of the tumour, usually over 20 years and averaging $30-40$ years, which is unaffected by age at first exposure. ${ }^{8}$

Mesothelioma has a characteristic but not pathognomonic macroscopic appearance. It shows considerable histological diversity and its ability to mimic other tumours often makes diagnosis difficult. Good, well illustrated histopathological descriptions of these tumours are available ${ }^{9-11}$ but are beyond the scope of this article. There is no satisfactory treatment at present and the prognosis is very poor; most patients die within 18 months of diagnosis.

Most cases of malignant mesothelioma are associated with asbestos exposure but other causes are recognised. ${ }^{12}$ Since the paper by Wagner et al in $1960^{2}$ there has been an explosion of research and scientific publications on the topic and controversy over the roles of the different fibre types and their capacity to cause disease. There are several reasons for this controversy: (1) the scarcity of populations exposed to only one fibre type; (2) the long latent periods between exposure and the development of the disease; (3) the problems of diagnosis; and (4) the lack of satisfactory data on the airborne fibre levels to which workers have been exposed.

This review is an attempt to synthesise and put into perspective the current information contributed by epidemiological, pathological, and mineralogical investigations to our understanding of the role of the various mineral fibre types in the development of malignant mesothelioma. The evidence from in vitro and in vivo experiments will also be considered and their relevance to the human disease discussed.

\section{Mineralogy}

In this paper I use the term fibre for any fibrous inorganic or organic substance possessing a length to diameter (aspect) ratio of more than 3:1. Fibres may be classified into two major groups-natural and synthetic. The natural group includes the asbestos family and other acicular (asbestiform) fibres such as attapulgite, sepiolite, and zeolite (including erionite). Erionite, one of the fibrous zeolites, is found naturally in volcanic rocks. In some areas of Turkey it is similar in its physical characteristics to crocidolite but appears to be even more dangerous. The synthetic group contains over 70 minerals, including glass fibres, rock wool, slag wool, and ceramic fibres. These man made mineral fibres are being used increasingly and substituted for asbestos but as yet there is little information about their health effects. There is concern that they may ultimately cause diseases similar to those resulting from asbestos exposure. Reports of an excess of lung cancers among slag wool workers, in both Europe and the United States, have appeared but whether this is due to the slag wool itself, to contaminants, or to other factors is not yet clear. ${ }^{13}$ More long term studies, preferably including mineralogical examination of lung tissue, are needed to clarify this problem.

The term asbestos covers a group of naturally occurring inorganic, fibrous, crystalline, hydrous silicate minerals that possess high tensile strength, stability, and thermal properties. This group of minerals is widespread in nature and has been found in Arctic ice samples from 10000 years ago. ${ }^{14}$ There are two major groups-namely, serpentine and amphibole (fig 1). Serpentine includes the most commonly used asbestos mineral, chrysotile (white asbestos), whereas the amphibole group includes several fibre types, such as crocidolite (blue asbestos), amosite (brown asbestos), tremolite/actinolite, and anthophyllite. Chrysotile, crocidolite, and amosite have been the most commonly used industrially. Anthophyllite was exploited commercially in Finland up to 1974; it sometimes contaminates amosite and some chrysotile and talc deposits. ${ }^{15}$ Tremolite has recently been recognised as an important contaminant of some chrysotile, talc, and vermiculite deposits. ${ }^{16}$ These fibres have different chemical, physical, and biological properties and consequently different health effects. The physical dimensions and shape are particularly important in relation to their health effects.

The electron microscope shows that chrysotile is composed of very uniform fibrils that tend to form curly bundles, whereas the amphibole fibres are straight and rigid with parallel sides. The amphiboles vary in their aspect ratios and this influences their pathogenicity (fig 2).

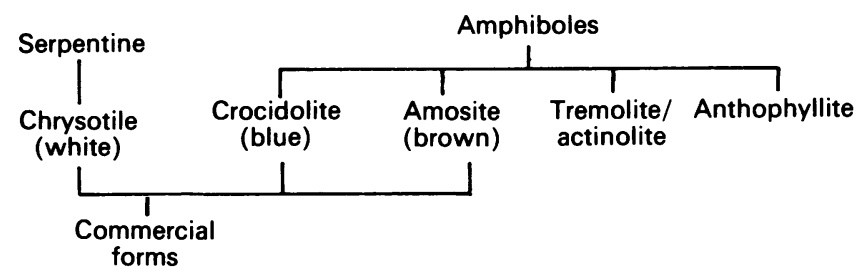

Figure 1 Classification of asbestos fibres. 

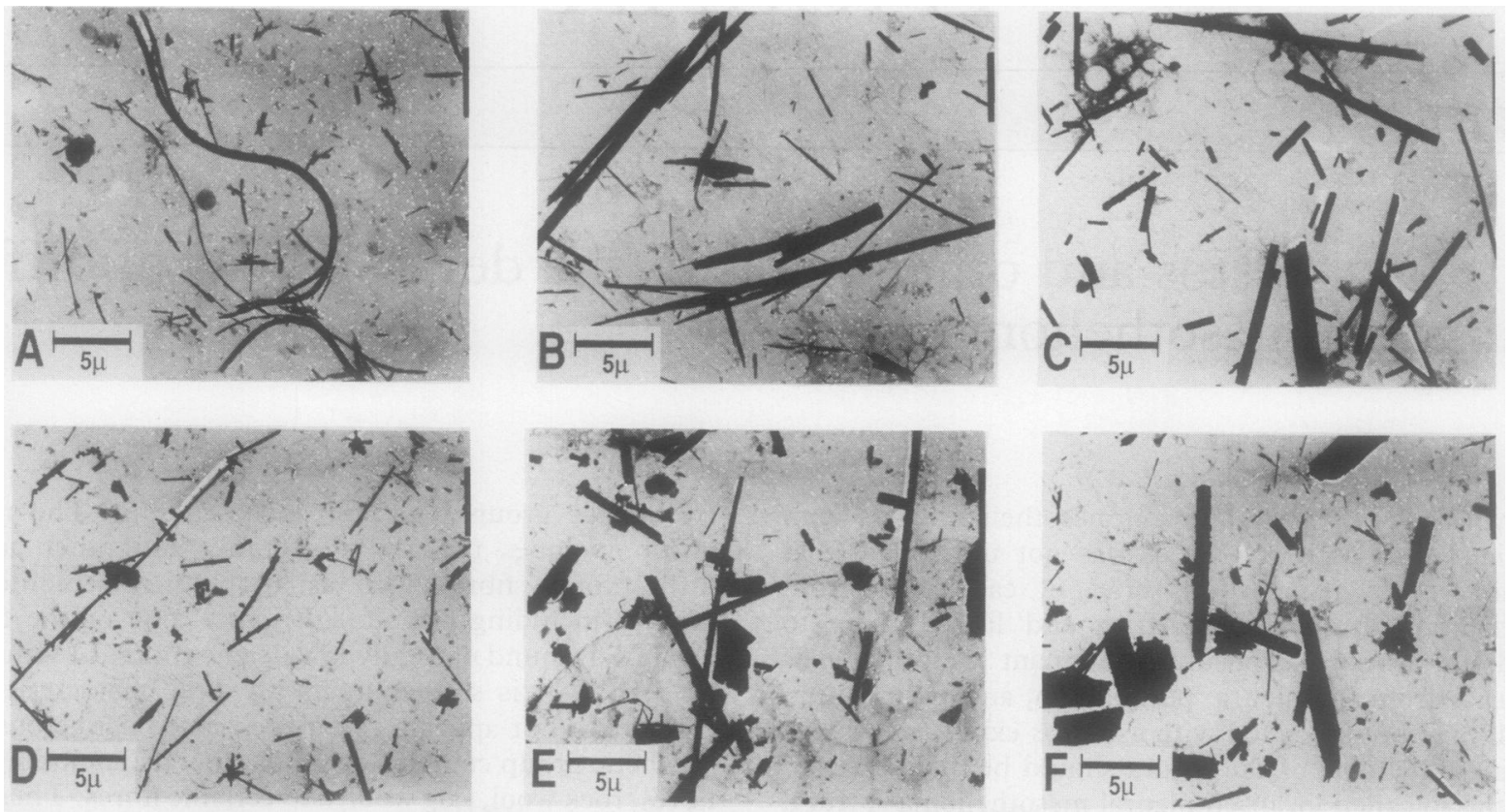

Figure 2 Transmission electron micrographs of mineral fibres: $A$-chrysotile; $B$-tremolite; $C$-amosite; $D$-crocidolite; $E$-anthophyllite; $F$-erionite. Reproduced by courtesy of $D M$ Griffiths.

DEPOSITION, DISTRIBUTION AND CLEARANCE OF FIBRES Information about the deposition of asbestos fibres within the lungs comes largely from animal studies. These have shown that the curly chrysotile fibres are more likely to be intercepted in the large airways, whereas thin, short amphibole fibres penetrate more deeply. ${ }^{17}$ After several months these tend to become localised in subpleural foci. ${ }^{18}$ Animal studies have suggested that interstitial fibrosis occurs in localised areas where the fibre concentration is greatest. ${ }^{19}$ Some corroborative evidence has come from human studies but these have produced conflicting results. In cases with exposure to asbestos but without fibrosis Sebastien $e t a l^{20}$ found an accumulation of asbestos fibres, particularly chrysotile, in the peripheral areas of the lung; but in those heavily exposed to asbestos who had fibrosis, however, the periphery of the lower lobe differed from the other areas of the lung. The smallest concentrations of fibres were present in the periphery of the lower lobe but they were the larger fibres. Short chrysotile fibres were also found in parietal pleural plaques. Gibbs et al, ${ }^{21}$ however, found that in cases of asbestos related diffuse pleural fibrosis the numbers of chrysotile fibres did not differ significantly between central, subpleural, and visceral pleural regions, but that the levels of amphiboles were much lower in the pleura than in the other sites. Nevertheless, occasional amphibole fibres were found within the visceral pleura.

There appear to be substantial variations in fibre accumulation within very small areas of the lungs. When examining different samples of subpleural tissue in nine cases with exposure to asbestos Churg and Wood ${ }^{22}$ found mean within case ratios of maximum to minimum fibre concentrations of 7.5 for amosite and crocidolite, $\mathbf{7 . 0}$ for tremolite, 3.8 for chrysotile, and 4.0 for non-asbestos fibres. When Churg and DePaoli ${ }^{23}$ examined fibre concentrations within the lungs of three groups of chrysotile miners and millers (11 who had died within two years of last exposure, seven who had died 12-15 years from last exposure, and five who had died more than 20 years after last exposure); they found no significant differences in length, width, aspect ratio, or concentration ratio of chrysotile to tremolite fibres between the three groups, suggesting that differences in fibre retention must reflect events occurring relatively early after inhalation. In rats exposed to asbestos by inhalation the amount of retained amphiboles increased linearly over time, whereas chrysotile after a relatively short time reached a steady state with equalisation between removal and deposition. ${ }^{24}$ Preferential clearing of short fibres also appears to occur in experimental animals, so that retained fibre length increases with time. ${ }^{25} 26$

\section{Animal studies}

A critical review of experimental approaches to fibre induced lung diseases has been produced by Wagner. ${ }^{27}$ Three main approaches have been used: (1) direct pleural implantation; (2) intratracheal injection; and (3) inhalation. Inhalation is the ideal method because it mimics most closely what happens in man, the material does not bypass the body's defence mechanisms, and the distribution of the fibres is more natural. The major disadvantages are that it is time consuming (tumours usually take two or three years to develop), complex, and prohibitively expensive. Moreover, except with erionite, there is a very low rate of malignant mesothelioma production. Implantation studies are cheaper and quicker, but they deliver very high doses of fibre to localised sites and bypass the normal defence mechanisms. They produce a relatively high rate of malignant mesothelioma. The results of these experiments may provide some useful information but should not be extrapolated to the human disease without corroborative evidence. Intratracheal experiments are also quicker and cheaper than the inhalation studies but again tend to deliver a large quantity of material to the trachea, which results in uneven pulmonary deposition, including large clumps that may block off airways. They also bypass the normal defence mechanisms. The classic implantation experiments by Stanton ${ }^{28}$ have shown that fibres greater than $8 \mu \mathrm{m}$ in length and less than $0.25 \mu \mathrm{m}$ in width are the most potent in producing malignant mesothelioma, and this has been corroborated by Wagner et al. ${ }^{29}$ When they 
were given by inhalation Davies et al found that short fibres of amosite (almost all fibres less than $5 \mu \mathrm{m}$ in length) were more likely to be retained in the lungs after 12 months than long fibres (more than $11^{\circ}$ o longer than $10 \mu \mathrm{m}$ ), but fibrosis developed only in the animals exposed to the long fibre preparation. ${ }^{30}$ One third of the animals exposed to the long fibre preparation developed lung tumours or malignant mesothelioma but none of those exposed to the short fibred preparation. They also performed intraperitoneal injections and found that $95^{\circ}$ of the animals given the long fibre preparation developed malignant mesothelioma, whereas only one animal exposed to short amosite fibres developed mesothelioma $\left(4^{\circ}{ }_{0}\right)$. The mean tumour induction period 520 days. When Wagner $e t a l^{31}$ injected the pleural cavities of rats with three samples of tremolite of different physical configurations mesothelioma developed only in rats injected with the sample containing a high proportion of long, thin fibres. Although the experiments had some technical weaknesses, there appeared to be a good correlation between the physical characteristics of the dust, in vitro toxicity, and in vivo carcinogenicity.

Spontaneously occurring malignant mesothelioma has, however, been described in several animals, including rats. ${ }^{32}$ Intraperitoneal injections of saline have produced malignant mesothelioma in animals of several species; a distinct background incidence appears to exist. Animal studies may provide useful information but care must be taken not to overinterpret them.

\section{Human studies \\ CHRYSOTILE}

Whether chrysotile contributes to the development of malignant mesothelioma has been controversial but the evidence that has come to light over recent years indicates that it is either very weakly carcinogenic or non-carcinogenic in man. Ninety five per cent of the world's production of asbestos is of chrysotile and the main producers are Canada, the Soviet Union, and Southern Africa. Studies of workers employed in the Quebec chrysotile production industry have provided very useful information about the relation of chrysotile exposure to lung disease. As the workers producing the asbestos would have had high exposures to chrysotile, estimates of disease in these workers should give an indication of possible risks to workers in other industries using chrysotile products. Asbestosis, excess lung cancers, and a few malignant mesotheliomas (a total of 10 up to 1980) have been found in the Quebec chrysotile miners and millers, and the risks appeared to increase with increasing dust exposure. ${ }^{33}$ It was later realised that the chrysotile ore contained a small proportion of tremolite (less than $1^{\circ}{ }_{0}$ ) and analyses of the fibre burden of. the lungs in some of the cases showed a substantial number of tremolite fibres. ${ }^{34-36}$ Furthermore, the risk of malignant mesothelioma appeared to increase directly with the increasing ratio of tremolite to chrysotile fibres in the lung tissues. ${ }^{34}$ In a report by Peto et al ${ }^{37} 17$ malignant mesotheliomas occurred in 850 men dying more than 20 years after exposure to asbestos at a Rochdale textile plant. These were initially attributed to chrysotile exposure because it was the predominant form of asbestos used, ${ }^{38}$ but it became apparent that appreciable quantities of crocidolite had been used at the factory. ${ }^{39}$ Further analysis of the lungs of workers who had been employed at the factory showed significantly raised levels of crocidolite. ${ }^{40}$ A study comparing the mortality of two groups of women, one exposed to chrysotile and the other to crocidolite when producing two different types of gas mask during the second world war, showed that malignant mesotheliomas developed in the latter but not the former. ${ }^{41}$
A study by Thomas et $\mathrm{al}^{42}$ of an asbestos cement plant that used chrysotile exclusively except during 1932-5, when crocidolite was used, found only two cases of mesothelioma and both occurred in workers exposed to crocidolite. Gylseth et $a l^{43}$ examined lung tissues from four cases of malignant mesothelioma and four cases of lung cancer that had occurred in workers at a Norwegian asbestos cement plant. Although the asbestos used from 1942 to 1980 had been $91 \cdot 7^{\circ}{ }_{0}$ chrysotile, $3 \cdot 1^{\circ}{ }_{0}$ amosite, $4 \cdot 1^{\circ}{ }_{0}$ crocidolite, and $1 \cdot 1{ }_{0}^{\circ}$ anthophyllite, scanning electron microscopy and $x$ ray microanalysis of lung tissue showed that $0-9 \%$ of the fibres were chrysotile whereas amphiboles ranged from $76^{\circ}{ }_{0}$ to $99^{\circ}{ }_{0}$. The study by Berry and Newhouse ${ }^{44}$ of the Ferodo friction products factory, where chrysotile was used apart from the occasional use of small quantities of crocidolite, found 10 patients in whom mesothelioma had occurred more than 10 years after first exposure. At least eight of these had been exposed to crocidolite whereas only three of the 40 workers chosen as controls had been exposed to crocidolite.

\section{CROCIDOLITE}

Crocidolite accounts for about $3^{\circ}{ }_{0}$ of the world's production of asbestos. Nowadays it nearly all comes from South Africa but in the past it was mined in Australia and Bolivia. Crocidolite is generally recognised as the most dangerous form of asbestos. Its use in several countries, including the United Kingdom, has been banned apart from very special applications. Its production continues, however, though it is not clear where the material is being used. The original discovery of an association between malignant mesothelioma and exposure to asbestos by Wagner et $a l^{2}$ was in subjects exposed to crocidolite in the North West Cape region of South Africa. An appreciable number of malignant mesotheliomas have developed in women who produced military gas masks containing crocidolite. ${ }^{41}{ }^{45}$ In some cases exposure was very short-only four months. There is little reliable information, however, about the levels of fibres to which crocidolite workers have been exposed apart from some preliminary data from 6506 men employed in crocidolite mining and milling in Wittenoom, Western Australia, during 1943-66. These men were followed to the end of 1980, when 31 had developed mesothelioma; ${ }^{46}$ no deaths from malignant mesothelioma occurred in workers who were employed for 90 days or less but men employed for longer periods showed about a 10 fold increase in mortality, with little indication of a gradient of increasing mortality with increasing duration of employment. There was a strong relation between death from malignant mesothelioma and the year of first employment but only weak evidence of an effect from intensity of exposure.

Interestingly, the incidence of malignant mesothelioma is strikingly lower in those exposed to crocidolite obtained from the Transvaal than in those exposed to the Northern Cape asbestos, ${ }^{47}$ with hardly any reported cases following exposure to Transvaal crocidolite but hundreds following exposure to asbestos from the Northern Cape. This may be because the Transvaal crocidolite has a greater diameter than that from the Northern Cape. ${ }^{48}$ In the United Kingdom most cases of malignant mesothelioma appear to be associated with crocidolite exposure. ${ }^{49} 50$

\section{AMOSITE}

Amosite accounts for about $1^{\circ}{ }_{0}$ of the world's production of asbestos and comes from South Africa. Less is known about its disease potential than that of crocidolite and chrysotile because populations exclusively exposed to it and to no other types of asbestos are rare. Webster ${ }^{47}$ reported 232 cases of malignant mesothelioma from South 
Africa, of which 78 developed in miners and millers of asbestos; of these, 75 were associated with the mining of Cape Blue (crocidolite) and two had exposure to amosite asbestos only. Factory workers from Patterson, New Jersey, where it was claimed that exposure was only to amosite and not to other forms of amphibole, have developed a large number of malignant mesotheliomas, with a particularly large number of peritoneal forms. ${ }^{51-54}$ These studies, however, were criticised by McCullagh, ${ }^{55}$ who suggested that insufficient attention was given to other possible sources of asbestos exposure before entry into the cohort under study. In the absence of any published studies of lung fibre analyses in these cases we cannot be certain that they were not exposed also to crocidolite. Mineral analyses of lung tissues have been performed on a few North American insulation workers and crocidolite as well as amosite has been found in some (F D Pooley and A R Gibbs, unpublished observations). Acheson $e$ t $a l^{56}$ studied 5969 men employed at a factory (Cape Boards, Uxbridge) that manufactured insulation board from 1947 to 1979 . Amosite was used predominantly, with small amounts of chrysotile but not crocidolite. Conditions were known to be very dusty in the plant before 1970 . They found five mesotheliomas, a doubling of lung cancer risk, and nine deaths from asbestosis up to 1980 . A study of the mineral content of the lungs from some of the workers who have died is under way but the results are not yet available. Amosite is generally agreed to be less carcinogenic than crocidolite but how much less is not certain.

\section{TREMOLITE/ACTINOLITE}

These minerals exist in nature in several physical forms and this appears to be important in determining what type of disease, if any, they cause. A considerable amount of evidence links the development of malignant mesothelioma with both occupational and environmental exposure to tremolite/actinolite fibres. Mineral ores from several industrial sources are contaminated by tremolite. The Quebec workers who mine and mill asbestos that is predominantly chrysotile are also exposed to tremolite, which is less than $1 \%$ of the ore. In the workers who show an excess risk of malignant mesothelioma, lung cancer, and fibrosis, ${ }^{33}$ however, examination of the lung tissue has shown a high tremolite content, ${ }^{57} 58$ whereas chrysotile had accumulated to a much smaller extent. At Libby, Montana, vermiculite, a micaceous mineral used in insulation, construction, and agricultural products, is mined and milled. The ore is contaminated by about $2 \%$ tremolite/actinolite fibres and it is of high aspect ratio. ${ }^{59}$ These workers have an excess of malignant mesotheliomas and lung cancers, believed to be caused by exposure to tremolite. ${ }^{6061}$ Seven cases of mesothelioma were found in a Swedish cement plant where the workers were exposed mainly to chrysotile asbestos but also to smaller amounts of commercial amphiboles. The geometric mean concentrations of total amphiboles (tremolite and crocidolite) in lung tissue from the patients with mesothelioma were significantly higher than in exposed workers who had not developed mesothelioma. ${ }^{62}$

There are now several reports of non-occupational malignant mesothelioma occurring in different geographical locations where inhalation of tremolite fibres has been implicated. Baris et $a l^{63}$ reported four patients with pleural malignant mesothelioma from a small Anatolian village, Caparkayi, in central Turkey. Tremolite was found in the lung tissue of one patient. It was suggested that the tremolite was inhaled from the walls of houses plastered with white stucco. Malignant mesotheliomas have also been reported in other Turkish districts where there are tremolite deposits that are quarried for use in whitewash. ${ }^{64}$ Boutin et $a l^{65}$ have recorded five pleural malignant mesotheliomas in people living in north east Corsica, where there are numerous asbestos outcrops. Airborne samples have shown high tremolite concentrations; heavy asbestos burdens have been present in the lungs of the mesothelioma patients. Tremolite has also been implicated as the cause of malignant mesothelioma in Cyprus $^{66}$ and in Metsovo, Greece. ${ }^{67}$ There is strong evidence that the potential for disease is associated with the physical configuration of the tremolite, and this is supported by the behaviour of the fibres in in vitro test systems. ${ }^{31}$

\section{ANTHOPHYLLITE}

Anthophyllite has been exploited in Finland and has been used as a cheap filler and as an insulation material. Pleural plaques have been found not only in anthophyllite miners but also in several hundred people living near but not working in the mines. ${ }^{68}$ A study of asbestos disease in Finland found no cases of mesothelioma in workers exposed to anthophyllite only. ${ }^{69}$ A recent study of 19 cases of mesothelioma from Finland showed a predominance of anthophyllite in the lungs in six cases. ${ }^{70}$ Anthophyllite was the most common amphibole found in the reference groups, however. Moreover, the analyses were carried out by scanning electron microscopy, which may have failed to detect very fine crocidolite fibres. The study is therefore inconclusive. Anthophyllite has a much greater diameter before milling than other commercially important amphiboles. Transmission electron microscopy of anthophyllite fibres in the lungs of workers from the Finnish anthophyllite mines showed a median diameter of $0.6 \mu \mathrm{m} .{ }^{71}$ This may account for the low mesothelioma potential of anthophyllite.

\section{NON-ASBESTOS RELATED MESOTHELIOMAS}

In the United Kingdom some $10-20 \%$ of cases of malignant mesothelioma are unrelated to asbestos exposure. These patients with no history of asbestos exposure have a lung mineral content similar to that of normal control subjects. ${ }^{72}$ In nearly all of these no cause can be found. Other causes of malignant mesothelioma have been proposed, ${ }^{12}$ including radiation, other minerals (such as silica, beryllium, and nickel), organic chemicals, viruses, and chronic inflammation. Spontaneous malignant mesothelioma has been described in various animal species, including the hamster and the rainbow trout. ${ }^{73}$ The evidence linking radiation with mesothelioma appears to be reasonably strong. Mesotheliomas have developed, in the absence of known exposure to asbestos, in areas of the body that had been irradiated many years previously ${ }^{74}$ but these are rare. The other possible causes listed above are very speculative, with few data to support them.

There is clear evidence that exposure to fibres other than asbestos may cause malignant mesothelioma in some areas of the world. There are certain villages in Turkey (Karain) where the houses are made out of volcanic material containing a fibrous zeolite called erionite. Inhabitants of these villages have a very high incidence of malignant mesothelioma. ${ }^{75}$ In experimental studies erionite has produced the highest rate of malignant mesothelioma. ${ }^{76}$

\section{Conclusions}

It is unfortunate that asbestos is often thought of as one mineral and that equal weight is sometimes given to all types for disease potential. Animal experiments provide useful information but should not be extrapolated too readily to man. Animal studies indicate that the physical characteristics of the fibre are important in disease causation. Recent human studies show that chrysotile has a 
much lower potential for causing disease than the amphibole minerals. There appears to be no good reason to ban the use of chrysotile asbestos and the policy of removing intact white asbestos from public buildings seems misplaced and wasteful of resources. It is better to use, with sensible precautions, materials that have been well studied than to rush into replacement with nonasbestos materials that have not been around for long enough for us to understand their disease producing potential.

A R GIBBS Research Group, Llandough Hospital, Penarth

Address for reprint requests: Dr A R Gibbs, Llandough Hospital, Penarth, S Glam CF6 1XX.

1 Wagner E. Das Tuberkelahnliche Lymphadenom (Der Cytogene oder reticulierte Tuberkl). Arch Heilk (Leipzig) 1870;11:497-525.

2 Wagner JC, Sleggs CA, Marchand P. Diffuse pleural mesothelioma and asbestos exposure in the north western Cape Province. Br J Ind Med 1960;17:260-71.

3 England DM, Hochholzer L, McCarthy MJ. Localized benign and malignant fibrous tumours of the pleura. Am J Surg Pathol 1989;13:640-58.

4 Spirtas R, Beebe GW, Connelly RR. Recent trends in mesothelioma incidence in the United States. Am J Ind Med 1986;9:397-407.

5 Jones RD, Smith DM, Thomas PG. Mesothelioma in Great Britain in 1968-83. Scand J Work Environ Health 1988;14:145-52.

6 Grundy GW, Miller RW. Malignant mesothelioma in children: report of 13 cases. Cancer 1972;30:1216-9.

7 Brewer J, Sordillo PP, Magill GB. Malignant mesothelioma in children: report of seven cases and review of the literature. Med Pediatr Oncol 1981;9:367-73.

8 Peto J, Seidman H, Selikoff IJ. Mesothelioma mortality in asbestos workers: implications for models of carcinogenesis and risk assessment. $\mathrm{Br} \mathrm{J}$ Cancer 1982;45:124-35.

9 Gibbs AR, Seal RME. Atlas of pulmonary pathology. Lancaster: MTP, 1982.

10 Churg A. Neoplastic disease caused by asbestos. In: Churg A, Green FHY, eds. Pathology of occupational lung disease. New York: Igaku Shoin, 1988;279-326.

11 McCaughey WTE, Kannerstein M, Churg J. Tumours and pseudotumours of the serous membranes. Washington, DC: Armed Forces Institute of Pathology, 1985. (Second series.)

12 Peterson JR, Greenberg SD, Buffler PA. Non-asbestos related malignant mesothelioma. Cancer 1984;54:951-60.

13 Enterline.PE. Role of manmade mineral fibres in the causation of cancer. $\mathrm{Br} \mathrm{J}$ Ind Med 1990;47:145-46.

14 Kohyama N. Airborne asbestos levels in non-occupational environments in Japan. In: Bignon J, Peto J, Saracci R, eds. Non-occupational exposure to mineral fibres. Lyon: International Ageing for Research in Cancer, 1989:262-76.

15 Pooley FD, Rowlands N. Chemical and physical properties of British talc powders. In: Walton WH, ed. Inhaled particles IV. Part 2. Oxford: Pergamon, 1977:639-46.

16 Lockey JE, Brooks SM, Jarabek AM, et al. Pulmonary changes after exposure to fibrous vermiculite contaminated with fibrous tremolite. $\mathrm{Am}$ Rev Respir Dis 1984;129:952-8.

17 Harris RL, Timbrell V. The influence of fibre shape in lung depositionmathematical estimates. In: Walton WH, ed. Inhaled particles IV. Part 1. Oxford: Pergamon, 1977:75-89.

18 Morgan A, Evans JC, Holmes A. Deposition and clearance of inhaled fibrous minerals in the rat. Studies using radioactive tracer techniques. In: Walton minerals in the rat. Studies using radioactive tracer techniques. In: Walton

19 Pinkerton KE, Pratt PC, Brody AR, Crapo JD. Fiber localization and its relationship to lung reaction in rats after chronic inhalation of chrysotile asbestos. Am J Pathol 1984;117:484-98.

20 Sebastien P, Fondimare A, Bignon J, Monchaux G, Desbordes J, Bonnaud $G$. Topographical distribution of asbestos fibres in human lung in relation to occupational and non-occupational exposure. In: Walton WH, ed. Inhaled particles IV. Part 2. Oxford: Pergamon, 1977:435-46.

21 Stephens M, Gibbs AR, Pooley FD, Wagner JC. Asbestos induced pleural fibrosis: pathology and mineralogy. Thorax 1987;42:583-8.

22 Churg A, Wood P. Observations on the distribution of asbestos fibres in human lungs. Environ Res 1983;31:374-80.

23 Churg A, DePaoli L. Environmental pleural plaques in residents of a Quebec mining town. Chest 1988;94:58-60.

24 Wagner JC, Berry G, Skidmore JW, Timbrell V. The effects of the inhalation of asbestos in rats. Br J Cancer 1974;29:252-69.

25 Holmes A, Morgan A. Clearance of anthophyllite fibers from the rat lung and the formation of asbestos bodies. Environ Res 1980;22:13-21.

26 Roggli V, Brody AR. Changes in numbers and dimensions of chrysotile asbestos fibers in lungs of rats following short term exposure. Exp Lung Res 1984;7:133-47.

27 Wagner JC. Experimental asbestosis. In: Gil J, ED. Models of lung disease: microscopy and structural methods. New York: Dekker (in press).

28 Stanton MF, Layard M, Tegeris A, et al. Relation of particle dimension to carcinogenicity in amphibole asbestoses and other fibrous minerals. J Natl Cancer Trust 1981;67:965-75.

29 Wagner JC. Significance of the fibre size of erionite [abstract]. In: Proceedings of International Pneumoconiosis Conference. Pittsburg, Pennsylvania, 1988:13. (Book resulting from meeting not yet published.)
30 Davis JMG, Addison J, Bolton RE, Donaldson K, Jones AD, Smith T. The pathogenicity of long versus short fibre samples of amosite asbestos administered to rats by inhalation and intraperitoneal injection. $\mathrm{Br} J \operatorname{Exp}$ Pathol 1986;67:415-30.

31 Wagner JC, Chamberlain M, Brown RC, et al. Biological effects of tremolite. Br J Cancer 1982;45:352-60.

32 Ilgren EB. Mesothelioma threshold. In: Mossman BT, Begin RO, eds. Effect of mineral dust on cells. Berlin: Springer, 1989:455-64. (NATO ASI series. Vol H30.)

33 McDonald JC, Liddell FDK, Gibbs GW, Eyssen GE, McDonald AD. Dust exposure and mortality in chrysotile mining, 1910-75. Br J Ind Med 1980;37:11-24.

34 Churg A, Wiggs B. Fibre size and number in users of processed chrysotile ore, chrysotile miners, and members of the general population. Am J Ind Med 1986;9:143-52.

35 Pooley FD. An examination of the fibrous mineral content of asbestos lung tissue from the Canadian chrysotile mining industry. Environ Res 1976;12:281-98

36 Rowlands N, Gibbs GW, McDonald JC. Asbestos fibres in the lungs of chrysotile miners and millers. Ann Occup Hyg 1982;26:411-5.

37 Peto J, Doll R, Hermon C, Binns W, Clayton R, Goffe T. Relationship of mortality to measures of environmental asbestos pollution in an asbestos textile factory. Ann Occup Hyg 1985;29:305-55.

$3 \overline{8}$ Peto $\bar{J}$. The hygiene standard for chrysotile asbestos. Lancet 1978;i:484-9.

39 Berry G, Gilson JC, Holmes S, Lewinsohn HC, Roach SA. Asbestosis: a study of dose-response relationships in an asbestos textile factory. $\mathrm{Br} \mathrm{J}$ Ind Med 1979;36:98-112.

40 Wagner JC, Berry G, Pooley FD. Mesotheliomas and asbestos type in asbestos textile workers: a study of lung contents. $\mathrm{Br}$ Med J 1982;285: 603-6.

41 Acheson ED, Gardner MJ, Pippard EC, Grime LP. Mortality of two groups of women who manufactured gas masks chrysotile and crocidolite asbestos: a 40 year follow-up. Br J Ind Med 1982;39:344-8.

42 Thomas HF, Benjamin IT, Elwood PC, Sweetnam PM. Further follow-up study of an asbestos cement factory. Br J Ind Med 1982;39:273-6.

43 Gylseth B, Mowe G, Wannag A. Fibre type and concentration in the lungs of workers in an asbestos cement factory. Br J Ind Med 1983;40:375-9.

44 Berry G, Newhouse ML. Mortality of workers manufacturing friction materials using asbestos. $\mathrm{Br} J$ Ind Med 1983;40:1-7.

45 McDonald AD, McDonald JC. Mesothelioma after crocidolite exposure during gas mask manufacture. Environ Res 1978;17:340-6.

46 DeKlerk NH, Armstrong BK, Musk AW, Hobbs MST. Cancer mortality in relation to measures of occupational exposure to crocidolite at Wittenoom Gorge in Western Australia. Br J Ind Med 1989;46:529-36.

47 Webster I. Asbestos and malignancy. $S$ Afr Med J 1973;47:165-71.

48 Timbrell V, Griffiths DM, Pooley FD. Possible biological importance of fibre diameters of South African amphiboles. Nature 1971;232:55-6.

49 Wagner JC, Moncrieff CB, Coles R, Griffiths DM, Munday DE. Correlation between fibre content of the lungs and disease in naval dockyard workers. Br J Ind Med 1986;43:391-5.

50 Jones JSP, Pooley FD, Clarke NJ, et al. The pathology and mineral content of lungs in cases of mesothelioma in the United Kingdom in 1976. In: Wagner JC, ed. Biological effects of mineral fibres. Lyon: International Agency for Research in Cancer, 1980;187-200. (IARC Scientific Publications 30 .)

51 Selikoff IJ, Hammond EC, Seidman H. Mortality experience of insulation workers in the United States and Canada 1943-1976. Ann NY Acad Sci 1979;330:91-116.

52 Seidman H, Lilis R, Selikoff IJ. Short term asbestos exposure and delayed cancer. In: Neibergs HE, ed. Third international symposium on prevention and detection of cancer. New York: Dekker, 1976:943-60.

53 Seidman H, Selikoff IJ, Gelb SK. Mortality experience of amosite asbestos factory workers: dose response relationships 5 to 40 years after onset of short term work exposure. Am J Ind Med 1986;10:479-514.

54 Ribak J, Seidman H, Selikoff IJ. Amosite mesothelioma in a cohort of asbestos workers. Scand J Work Environ Health 1989;15:106-110.

55 McCullagh SF. Amosite as a cause of lung cancer and mesothelioma in humans. J Soc Occup Med 1980;30:153-6.

56 Acheson ED, Gardner MJ, Winter PD, Bennett C. Cancer in a factory using amosite asbestos. Int J Epidemiol 1984;13:3-10.

57 Churg A, Wiggs B, Depaoli L, Kampe B, Stevens B. Lung asbestos content in chrysotile workers with mesothelioma. Am Rev Respir Dis 1984, 130:1042-5.

58 Churg A, Wright JL, DePaoli L, Wiggs B. Mineralogic correlates of fibrosis in chrysotile miners and millers. Am Rev Respir Dis 1989;139:891-6.

59 Moatamed F, Lockey JE, Parry WT. Fibre contamination of vermiculites: a potential occupational and environmental health hazard. Environ Res 1986;41:207-18.

60 McDonald JC, McDonald AD, Armstrong B, Sebastien P. Cohort study of mortality of vermiculite miners exposed to tremolite. $\mathrm{Br} J$ Ind $\mathrm{Med}$ 1986;43:436-44.

61 Amandus HE, Wheeler R. The morbidity and mortality of vermiculite miners and millers exposed to tremolite-actinolite. Am J Ind Med 1987;11:15-26.

62 Albin M, Johansson L, Pooley FD, Jakobsson K, Attewell R. Mineral fibres, fibrosis, and asbestos bodies in lung tissue from deceased asbestos-cement workers. Br J Ind Med (in press).

63 Baris YI, Artvinli M, Sahin AA, Bilir N, Kalyoncu F, Sebastien P. Nonoccupational asbestos related chest diseases in a small Anatolian village. Br J Ind Med 1988;45:841-2.

64 Yazicioglu S, Ilcayto R, Balci K, Sayli BS, Yorulmaz B. Pleural calcification, pleural mesotheliomas and bronchial cancers caused by tremolite dust. Thorax 1980;35:564-9.

65 Boutin G, Viallat JR, Steinbauer J, Dufour G, Gaudichet A. Bilateral pleural plaques in Corsica: a marker of non-occupational asbestos exposure. In Bignon J, Peto J, Saracci R, eds. Non-occupational exposure to mineral fibres. Lyon: International Agency for Research in Cancer, 1989:406-10. 
(IARC Scientific Publications 90.)

66 McConnochie K, Simonato L, Mavrides P, Christifides P, Pooley FD, Wagner JC. Mesotheliomas in Cyprus: the role of tremolite. Thorax 1987;41:342-7.

67 Langer AM, Nolan RP, Constantopoulous SH, Moutsopoulos HM. Association of Metsovo lung and pleural mesothelioma with exposure to tremolite-containing whitewash. Lancet 1987; ;:965-7.

68 Kiviluoto R. Pleural plaques and asbestos: further observations on endemic and non-occupational asbestosis. Ann NY Acad Sci 1965;132:235-9.

69 Huuskonen MS, Ahlman K, Mattson T, Tossavainen A. Asbestos disease in Finland. J Occup Med 1980;22:751-4.

70 Tuomi T, Segerberg-Konttinen M, Tammilehto L, Tossavainen A, Vanhala E. Mineral fiber concentration in lung tissue of mesothelioma patients in Finland. Am J Ind Med 1989;16:247-54.

71 Timbrell V. Deposition and retention of fibres in the human lung. Ann Occup
Hyg 1982;26:347-68.

72 Gibbs AR, Jones JSP, Pooley FD, Griffiths DM, Wagner JC. Nonoccupational malignant mesotheliomas. In: Bignon J, Peto J, Saracci R, eds. Non-occupational exposure to mineral fibres. Lyon: International Agency for Research in Cancer, 1989:219-228. (IARC Scientific Publications 90 .)

73 Pelnar PV. Further evidence of non-asbestos related mesothelioma. Scand J Work Environ Health 1988;14:141-4.

74 Antman KH, Ruxer RL, Aisner J, Vawter G. Mesothelioma following Wilm's tumour in childhood. Cancer 1985;54:367-9.

75 Baris I, Simonato L, Artvinli M, et al. Epidemiological and environmenta evidence of the health effects of exposure to erionite fibres: a four-year study in the Cappadocian region of Turkey. Int J Cancer 1987;39:10-7.

76 Wagner JC, Skidmore JW, Hill RJ, Griffiths DM. Erionite exposure and mesotheliomas in rats. Br J Cancer 1985;51:727-30. 